Journal of Economics and Behavioral Studies

Vol. 7, No. 3, pp. 76-87, June 2015 (ISSN: 2220-6140)

\title{
The Impact of Entrepreneurial Orientation, Reconfiguring Capability and Moderation of Environmental Turbulence on Export Performance of SMEs in Nigeria
}

\author{
Abiodun Tope Samson, Rosli Mahmood \\ UUM College of Business, Kedah Darul Aman, Malaysia \\ samsontope@yahoo.com
}

\begin{abstract}
Entrepreneurial orientation encapsulate the firm -level process, practice and strategic orientation while dynamic capabilities view of firm consists of the structure routine and processes that constitute its ability to reconfigure its asset base to match the requirement of the changing environment. The aim of this research emanated from the fact that only few studies examined how entrepreneurial strategic orientation and reconfiguring capability impact on export performance of SMEs in turbulent environment. In order to fill this vacuum, this study delineated relationship among these constructs and employed PLS-SEM on data collected from 201 exporting SMEs in Nigeria. The findings of the study suggest that entrepreneurial orientation, reconfiguring capability, and environmental turbulent significantly related to export performance. Environmental turbulence moderates the relationship between entrepreneurial orientation, reconfiguring capability and export performance. This suggests that SMEs could benefit from reconfiguring and renewal of their asset base and act in response to opportunities and threat to realize first order transformation in growth and export performance. Besides, this study also provides research conclusion to the appropriateness of entrepreneurial orientation and reconfiguring capability when there is environmental turbulence and their lack of effectiveness when there is stability.
\end{abstract}

Keywords: Entrepreneurial Orientation, Reconfiguring Capability, Environmental Turbulence, Small and Medium Enterprises, Export Performance

\section{Introduction}

Across the globe today Small and Medium Enterprises (SMEs) have continued to be relevant in the roles of development, industrialization, poverty reduction, wealth generation, employment provision and growth of many developed and developing countries (Ogunsiji, 2010). However, SMEs in developing countries have performed below expectation in their important roles of promoting and developing economic growth (Onugu, 2005). The Major researchers in SMEs in Nigeria have concentrated on finance as the basic obstacle of SMEs, While some acknowledged the firms are operating in turbulent environment(Ogunsiji, 2002). Several studies also identified monumental challenges such as weak strategic orientations, poor infrastructure, inadequate capabilities, poor management and inadequate technological skills' development and lack of export market knowledge/experience (Adegbite, Ilori, Irefin, Abereijo \& Aderemi, 2007). Responses to this critical situation culminated to yearly budgetary allocation, favorable policies, favorable pronouncement, incentives and regulations giving by local government, state government and federal government in order to diversify the revenue base (Oyefuga, Siyanbola, Afolabi \& Dada, 2008).

Surprisingly, the situation becomes more disturbing, confusing and critical when the degree of poverty, unemployment and hunger that SMEs supposed to reduce continue to increase at alarming rate, in spite of all intervention's strategies, drastic measures and incentives provided yearly (Anger, 2010). A study carried out by Manufacturing Association of Nigeria (MAN) showed that just about 10 percent of industries run by its members are completely in operation. The vast majority of SMEs die before their first to five years of operation, while some disappear within sixth and tenth year of existence and the remaining ones that grow to maturity are less than five to ten percent (Onugu, 2005). Okpara (2009) revealed that the non SMEs export at independence in 1960 provided $85 \%$ of total export earning and 63\% of gross domestic earning. But today, the case is different, despite the fact that $90 \%$ percent of the total manufacturing industries in Nigeria are SMEs, up till this moment insignificant numbers or less than $20 \%$ are able to export their total output (Julien \& Ramangalahy, 2003; Okpara \& Koumbiadis, 2009). 
Nevertheless, Teece, Pisano, and Shuen (1997) revealed that the major objective of the strategic management field is to make available philosophical and theoretical explanation of how a firm gains a competitive advantage. Dynamic capabilities' frame work contained by strategic management argues that a firm that can build up innovative capabilities and resources crucial to addressing changes in the external environment by integrating updating its already available capabilities would achieve competitive advantages (Teece et al., 1997). The reviews on literature have shown that study on dynamic capability View have only focused on established organization, this neglects new ventures and SMEs, Hence, the skills and competencies of SMEs need to be reconfigured, upgraded and recombined to ensure successful adaptation for growth (Sapienza, Autio, George \& Zahra, 2006; Zahra, Sapienza \& Davidsson, 2006). Studies have shown successful entry and survival especially in exporting as a result of dynamic capabilities (Sapienza et al., 2006). Hence, the basic objective of this study is to employ strategic entrepreneurial orientation, reconfiguring capability and environmental turbulence as fundamentals to predict export performance in Nigeria under the guide of resources based view and dynamic capability view.

\section{Entrepreneurial Orientation and export performance}

An entrepreneurial firm is the one that engages in product innovation, always undertake risky ventures, and is always the first to come up with proactive innovation, beating competitors to a punch (Miller \& Friesen, 1983). Several studies suggested that EO is the key to achieve competitive advantages and avenue to stimulate profitable performance (Zahra \& Covin, 1995). Therefore, being proactive, innovative, and risk taking could lead to superior performance (Lumpkin \& Dess, 1996). In the context of export venture, limited studies have investigated the roles of entrepreneurial oriented activities and its components in achieving superior performance. Management towards risk- taking was positively related to export performance and firms that are more open to innovation perform better in export business (Calantone, Kim, Schmidt \& Cavusgil, 2006). Balabanis and Katsikea (2003) studied the relationship between implementation of entrepreneurial oriented behavior and export performance in UK and found out that EO has a positive relationship with export performance. In a nut shell, the argument of the statistically significant relationship between export performance and EO can be established on the following: First, prime mover advantage implied by EO (Wiklund, 1999; Zahra \& Covin, 1995), where Pro-activeness, innovativeness and risk taking enable a firm to transform its economic performance (Naman \& Slevin, 1993). In addition, the complex, unpredictable and turbulent nature of export market environment encourage and provide better avenue for higher performance (Balabanis \& Katsikea, 2003). Adopting EO in exporting SMEs would boost SMEs' export performance (Knight \& Cavusgil, 2004). Thus being entrepreneurially postured or oriented would assist SMEs' exporters to achieve success. Therefore the following hypothesis is posited:

\section{H1: There is a significant relationship between Entrepreneurial orientation (EO) and export performance.}

Reconfiguring Capability and Export Performance: Reconfiguring capability (RC) can be referred to as ability to redesign certain element or components of a system. Addition or deletion of product line from the boundary of the firm or movement of product line between the unit boundaries of the firm (Karim \& Mitchell, 2004). Dynamic capabilities' frame work contained by strategic management argues that a firm that can build up innovative capabilities and resources crucial to addressing changes in the external environment by integrating updating its already available capabilities would achieve a competitive advantage (Teece et al., 1997). Meanwhile, reconfiguring capabilities (RCs) are innovative capabilities that can be used to address changes of firms' capabilities in dynamic environment in order to achieve competitive advantage. International entrepreneurship (export related activities) involves expanding the firm's operations into new geographical market as well as presents opportunity for growth and value creation (Jantunen, Puumalainen, Saarenketo \& Kyläheiko, 2005). This implies that reconfiguring capability is an appropriate mechanism that could impact on export performance. Secondly, Firm employs RCs to be familiar with environment and take action concerning opportunities and threat by extending, modifying, changing and creating firm's ordinary capabilities to achieve first order change (Winter, 2003), and reconfiguring capability would have an impact on export performance through modification, change and recreation in order to improve the performance of the firm. Therefore a high level of activities in term of implementing organizational changes and proficiency in reconfiguring actions would have positive effect on export performance. Having considered the above discussion, this study hypothesizes that: 


\section{H2: There is significant relationship between reconfiguring capabilities and export performance}

Environmental Turbulence and Export performance: A turbulent environment is an environment with high degree of inter-period change that causes dynamism and uncertainty. This type of environment is characterized with unfamiliar, hostile, heterogeneous, uncertain, complex, dynamic and volatile. Combined jointly, these descriptions amount to a measure of environmental turbulence (Covin \& Slevin, 1989; Dess \& Beard, 1984; Eisenhardt \& Bourgeois, 1988; Glazer \& Weiss, 1993). For an export firms to succeed and have sustainable competitive advantage would depend on its ability to find its feet to the varying environment through the support of tactical and strategic orientations. Hence, the complexity and turbulence nature of international enviroment would always increase the needs for strategic activities and planning. Cavusgil and Zou (1994) contended that this has a positive implication on export performance. This is practical to observe for firms that are operating in overseas marketing and vulnerable to vary and complicated environmental context both at industrial level, firm's level and even in their host and home country. It is now left for such SMEs in turbulence environment to adopt the best strategic approach to face and challenge the situation at hand in order to succeed in foreign market (Kaynak \& Kuan, 1993). It has been proposed that firms should align with environmental conditions in order to realize superior performance in abroad, accordingly environmental turbulence would have impact on export performance as environmental characteristics post specific challenges when the firm cross boarder (Sundqvist, Kyläheiko, Kuivalainen \& Cadogan, 2012). This further implies that the more turbulent the market needs, the more creative firms would be even though explorative activities in turbulence environment are inherently risky, activities increase the likelihood of achieving higher performance level above historical average (Garcia \& Calantone, 2002). Therefore this study proposes that:

\section{H3: Environmental turbulence is significantly related to export performance}

Environmental Turbulence and Entrepreneurial orientation: Environmental turbulence is a potential contingent factor that may influence the effectiveness of the usage of the strategic orientations. Lumpkin and Dess (2001) contended that when the environment is turbulent, hostile, full of uncertainty, the qualities associated with entrepreneurial orientation can be justified for its ability to seize new market and opportunity in spite of unfriendly situation. Several scholars like Miller and Friesen (1983), Covin and Slevin (1989), Lumpkin and Dess (2001), Wiklund and Shepherd (2005), and Boso, Cadogan and Story (2012) subscribed to the fact that only through adopting an entrepreneurial orientations can exporting firms effectively deal with prevalent forces in turbulent, hostile and dynamic export market. Wiklund and shephered (2005) declared that turbulent environment where demand regularly shift, opportunities turn out to be plentiful and performance level is expected to be at peak for firms that have special orientation in chasing after new opportunities since they possess a good fit/match between their orientation's strategy and the external environment ( Zahra \& Covin, 1995). Hence, this study hypothesizes the following:

H4: Environmental turbulence moderates the relationship between entrepreneurial orientation and export performance

Environmental Turbulence and Reconfiguring Capability: Reconfiguring capability is ability to build, integrate and reconfigure both external and internal resources and routine to address rapidly changing environment (Teece et al., 1997; Zahra \& George, 2002). While environmental turbulence is an environments with high degree of inter-period change that cause dynamism and uncertainty. Reconfiguring capabilities could help firms to reconfigure existing functional capabilities so that they can build products that better match emerging customer needs and take advantage of technological breakthroughs and impact on export performance. Consequently, when there is high degree of turbulent environment there would be higher risk and uncertainty and reinforcing high level of proactive approach would be needed in the strategic planning process (Lindelöf \& Löfsten, 2006). Adaptive capability emphasizes on the reconfiguration of resources and processes to respond to external change (Gibson \& Birkinshaw, 2004). Therefore, for an export firms to succeed and have sustainable competitive advantage would depend on its ability to find its feet to the varying environment through the support of tactical and reconfiguring capabilities. Hence, the complexity and tubulence of international enviroment would always increase the needs for strategic activities and planning. Turbulent environment which sometimes characterize with high-tech industries were established to promote entrepreneurial firm-level behavior and it is potential contingent factor that may influence the effectiveness 
of the usage of the strategic and international capability (Miller, Dröge \& Toulouse, 1988; Yeoh \& Jeong, 1995). Therefore, this study hypothesizes that:

H5: Environmental turbulence moderate the relationship between reconfiguring capability and export performance

\section{Methodology}

A questionnaire survey was carried out among a population of SMEs that are participating in exporting in Nigeria. The sample of this study was selected from the population sampling frames; Manufacturing Association of Nigeria (MAN) Export promotion Group Directory. From this directory, about five industrial sectors were selected. About 2200 firms were identified as qualified because they met the criteria specified. To select a sample size for the population of 2200, Krejcie and Morgan (1970) sample size determination's table was used. The table showed that 331 sample sizes would be required for the population of 2200 . In order to make provision for response bias an additional $40 \%$ of 331 was added making 457 sample size. Proportionate stratified and systematic samplings were employed. About twenty five days after the questionnaires have been emailed to the respondents, 118 completed questionnaires were received through e-mail and these 118 questionnaires were regarded as early responses which were further used to assess non response bias on the actual variables. In order to improve the response rate, a follow-up phone calls and series of Short Message Service (SMS) were sent to remind the SMEs 'managers who were yet to return their questionnaires. This effort yielded the largest numbers of response compared to the first response. About 120 questionnaires were returned. It was tagged as late responses which were later used to assess non-response bias. Out of 457 questionnaires that were emailed to the selected respondents, a total of 238 were returned, out of these, 2 were not usable due to excessive missing data, 2 were completely eliminated due to their selection of option 'services/government' and not 'manufacturing' as primary area of business, 2 were also removed for selection of option 'total cost of business that above \#200,000,000' specified as a criteria for SMEs and 2 were also eliminated due to low level of knowledge on the topic of interest, remaining 230 useable questionnaire. Hence, the response rate was calculated as $50 \%$, which is sufficient enough for the study (Sekaran \& Bougie, 2013). In the course of preliminary analysis, 29 out 230 useable questionnaires were removed for being detected as multivariate outliers. The final data set for the study remained 201.

Measures: Entrepreneurial orientation (EO) was measured in this study by nine items of Covin and Slevin (1989). Reconfiguring capability was measured by seven item employed by Jantunen et al. (2005) to assess the success of renewal activities carried out in the community innovation survey of the European Union. Environmental turbulence's measure were adopted from Cadogan, Paul, Salminen, Puumalainen, and Sundqvist (2001) who employed measures originally used by Kohli, Jaworski, and Kumar (1993) and later adapted them in an export context. Jantunen et al. (2005) computed this scale as mean of seven items. Export performance was measured by Expert scale that was built on Cavusgil and Zou (1994) (Okpara \& Kabongo, 2009; Zou, Taylor \& Osland, 1998). The nine items adapted from Zou et al. (1998) called Expert scale was used to measure export performance in this study.

\section{Results and Discussion}

Data Analysis: The present study employed PLS path modeling (Wold, 1985), to assess and test the theoretical model. The suitability of PLS-SEM is based on the fact that the nature of the present study to some extent required explorative tool to extend some of the constructs used in the study. PLS-modeling has also been suggested as prediction oriented for an extension of any existing theory (Henseler, Ringle, \& Sinkovics, 2009). Against this background, the present study employed a two step process to calculate and report the result of PLS-SEM path as suggested by Henseler, Ringle and Sinkovics (2009). These two -step processes are (1) the assessment of measurement model and (2) the assessment of a structural model (Henseler \& Ringle, 2009).

Assessment of measurement Model: The PLS -SEM algorithm in the first stage; all the constructs scores are estimated to determine items reliability, internal consistency, convergent validity and discriminant validity. The indicators with outer loadings between 0.40 and 0.70 were retained, while some items below the threshold of 0.40 were deleted (Hair, Hult, Ringle \& Sarstedt, 2013). About 7 items were deleted out of 32 
items. The remaining 25 items were retained as they have loadings that range between 0.5879 and 0.9381 , this shows individual items reliability. In table 1 the composite reliability of each construct ranges between 0.817 and 0.929 which is considered satisfactory and AVE of each construct ranges between 0.533 and 0.794 which is also sufficient above the .50 threshold. This means internal consistency has been achieved in the present study. Table 1 depicts the items loadings, composite reliability and average variance extracted of the present study.

Table 1: Loadings, composite Reliability (CR) and Average Variance Extracted (AVE)

\begin{tabular}{|c|c|c|c|c|}
\hline Constructs & Items & Loadings & AVE & Composite $\mathrm{R}$ \\
\hline \multirow{5}{*}{ Entrepreneurial Orientation } & E001 & 0.6724 & 0.5237 & 0.8454 \\
\hline & EO02 & 0.7003 & & \\
\hline & EO05 & 0.6717 & & \\
\hline & E006 & 0.7619 & & \\
\hline & EO09 & 0.8026 & & \\
\hline \multirow[t]{7}{*}{ Reconfiguring Capability } & RCD01 & 0.5879 & 0.6568 & 0.9297 \\
\hline & RCD02 & 0.847 & & \\
\hline & RCD03 & 0.8816 & & \\
\hline & RCD04 & 0.86 & & \\
\hline & RCD05 & 0.7716 & & \\
\hline & RCD06 & 0.858 & & \\
\hline & RCD07 & 0.8286 & & \\
\hline \multirow[t]{4}{*}{ Environmental Turbulence } & ET003 & 0.8447 & 0.5304 & 0.8172 \\
\hline & ET004 & 0.7265 & & \\
\hline & ET005 & 0.6453 & & \\
\hline & ET007 & 0.6811 & & \\
\hline \multirow[t]{3}{*}{ Finance } & FIN01 & 0.8629 & 0.6924 & 0.8702 \\
\hline & FIN02 & 0.7304 & & \\
\hline & FIN03 & 0.894 & & \\
\hline \multirow[t]{3}{*}{ Strategy } & STG01 & 0.6978 & 0.6882 & 0.8675 \\
\hline & STG02 & 0.9001 & & \\
\hline & STG03 & 0.8761 & & \\
\hline \multirow[t]{3}{*}{ Satisfactory } & SAT01 & 0.9381 & 0.7948 & 0.9207 \\
\hline & SAT02 & 0.8692 & & \\
\hline & SAT03 & 0.8654 & & \\
\hline
\end{tabular}

Some indicators were deleted and all the remaining indicator have high outer loadings on a construct indicating that the associated have much in common which shows this study achieved convergent validity. The average variance extracted was .50 and the square root of the AVE was greater than correlation among latent constructs which indicates discriminant validity was achieved (Hair, Sarstedt, Pieper \& Ringle, 2012). Table 2 depicts the square root of the average variance extracted and the correlation of latent variables.

Table 2: Square root of Average Variance Extracted and the correlation of latent Variables

\begin{tabular}{lllllll}
\hline Latent Variable & $\mathbf{1}$ & $\mathbf{2}$ & $\mathbf{3}$ & $\mathbf{4}$ & $\mathbf{5}$ & $\mathbf{6}$ \\
\hline Entrepreneurial Orientation & $\mathbf{0 . 7 2 3 6}$ & & & & & \\
Environmental Turbulence & 0.2652 & $\mathbf{0 . 7 2 8 2}$ & & & & \\
Reconfiguring Capability & 0.2886 & 0.5399 & $\mathbf{0 . 8 1 0 4}$ & & & \\
Satisfaction & 0.429 & 0.6472 & 0.5349 & $\mathbf{0 . 8 9 1 5}$ & & \\
Strategy & 0.3094 & 0.3843 & 0.5667 & 0.6488 & $\mathbf{0 . 8 2 9 5}$ & \\
finance & 0.301 & 0.3722 & 0.4968 & 0.5832 & 0.6971 & $\mathbf{0 . 8 3 2 1}$
\end{tabular}

Note: Diagonal elements (figures in bold) are the square root of the variance shared the construct and their measures. Off diagonal elements are the correlations among construct. 
Assessment of structural Model: Having confirmed that the construct measures are reliable and valid, the next line of action in this study was to address the assessment of the structural model result. Standard bootstrapping procedure was used with a number of 5000 bootstrap samples and 201 cases to assess the significance of the paths (Henseler et al., 2009). Figure 1 depicts how bootstrapping of PLS-SEM Algorithm was used to assess the significance of the path coefficients.

\section{Figure 1: Structural Model}

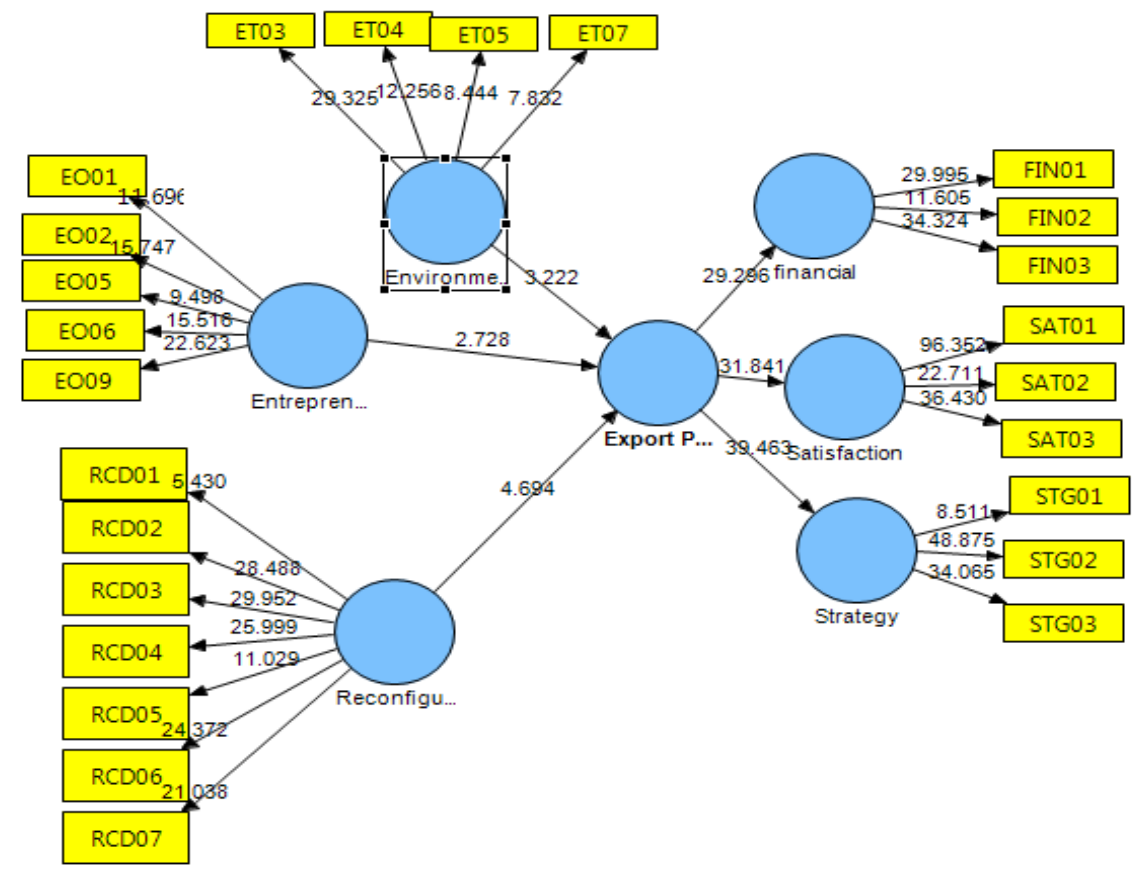

Table 3: The Result of structural Model and Moderator

\begin{tabular}{|c|c|c|c|c|c|}
\hline Relationship & $\beta$ & S. E. & T.S. & P. V. & Decision \\
\hline Entrepreneurial 0. -> Export P. & 0.2145 & 0.0786 & 2.729 & 0.003 & supported \\
\hline Environmental T -> Export P. & 0.2742 & 0.0851 & 3.222 & 0.000 & Supported \\
\hline Reconfiguring C. -> Export P. & 0.4033 & 0.0859 & 4.694 & 0.00 & Supported \\
\hline $\begin{array}{l}\mathrm{H} 4 \quad \text { Entrepreneurial } \\
\mathrm{T}->\text { Export } \mathrm{P} .\end{array}$ & 1.0316 & 0.5358 & 1.9253 & 0.027 & Supported \\
\hline $\begin{array}{l}\text { H5 Reconfiguring C. *Environmental T- >Export } \\
\text { P. }\end{array}$ & -0.9358 & 0.2993 & 3.1263 & 0.001 & Supported \\
\hline
\end{tabular}

Table 3 summarizes the result of reflective measured constructs (Entrepreneurial orientation, Environmental Turbulence, Reconfiguring Capability and Export Performance) by showing the original outer weight estimates, the $t$ values and the corresponding significance level marked in asterisks as well as the palues with the result of the mediating effect. Hypothesis 1 predicted that entrepreneurial orientation is significantly related to export performance, the finding on the relationship $(\beta=0.2145, t=2.7278, P=0.003)$ supported the relationship. While hypothesis 2 predicted reconfiguring capability is significantly related to export performance, the estimates of PLS-SEM bootstrapping with 201 cases indicated $(\beta=0.4033, t=-4.6938, p=$ 0.00 ) support for the relationship. Hypothesis 3 also predicted that environmental turbulence is significantly 
related with export performance, the finding of the study indicated support $(\beta=0.2742, t=3.222, P=0.000)$ for the relationship. Similarly, hypothesis 4 predicted that environmental turbulence moderate the relationship between entrepreneurial orientation and export performance the finding of the study supported $(\beta=1.0316$, $\mathrm{t}=1.9253, \mathrm{P}=0.027)$ the relationship. In the same vein hypothesis 5 predicted that environmental turbulence moderate the relationship between reconfiguring capability and export performance, the outcome of the bootstrapping PLS-SEM ( $\beta=-0.9358, t-3.1263$, P 0.001) support the relationship.

The $R^{2}$ value in this study is 0.48 which indicates that the predictive variables (entrepreneurial orientation, reconfiguring capability and environmental turbulence) explained $48 \%$ of the variance in endogenous variable (export performance) which is considered moderate (Hair, Ringle, \& Sarstedt, 2011). In addition to the assessment of $R^{2}$ values of all endogenous variables, this study also evaluates effect size. Table 4 shows the effect of exogenous latent variable on endogenous latent variables through the means of changes in the Rsquared (Chin, 1998).

Table 4: The Effect sizes of the latent Variable

\begin{tabular}{lccll}
\hline Variables & Included & Excluded & F. squared & Effect size \\
\hline Export P. & & & & \\
Entrepreneurial O. & 0.484 & 0.443 & 0.0795 & Small \\
Reconfiguring C. & 0.484 & 0.377 & 0.2074 & Medium \\
Environmental T. & 0.484 & 0.431 & 0.1027 & Small \\
\hline
\end{tabular}

Table 4 above depicts the effect sizes of the latent variables as small, medium and small respectively. In addition to evaluating effect sizes and magnitude of $\mathrm{R}^{2}$ values as a criterion for predictive accuracy. This study employed cross validated redundancy as supplementary assessment of goodness -of-fit (Duarte \& Raposo, 2010). A research model with $\mathrm{Q}^{2}$ statistics (s) greater than Zero is considered to have predictive relevance (Henseler et al, 2009). Table 5 depicts the cross validated redundancy for export performance (endogenous variables).

Table 5: Cross Validated Redundancy

\begin{tabular}{lccl}
\hline Total & SSO & SSE & 1-SSE/SSO \\
\hline Export Performance & 1809 & 1337.942 & 0.2604 \\
\hline
\end{tabular}

As shown in the Table 5, the cross- validation redundancy measure Q2 for the endogenous latent variable is above zero, this suggests predictive relevance of the study model (Henseler \& Ringle, 2009). Following the procedure recommended by Aiken and West (1993) and Dawson and Richter (2006), information from path coefficient was used to plot the moderating effect of environmental turbulence on the relationship between reconfiguring capability and export performance. The figure 2 below shows the interaction effect of reconfiguring capability and environmental turbulence on export performance. The moderating effect of environmental turbulence on the relationship between reconfiguring capability and export performance is shown. It shows a stronger positive relationship between entrepreneurial orientation and export performance for a firm with high environmental turbulence than for a firm with low environmental turbulence.

Discussion: The finding of this study indicated statistically significant relationship between entrepreneurial orientation and export performance. This is consistent with some earlier studies (Baker \& Sinkula, 2009; Balabanis \& Katsikea, 2003; Boso et al., 2012; Calantone et al., 2006; Cavusgil, 1984; Lechner \& Gudmundsson, 2014; Wiklund \& Shepherd, 2003; Zahra \& Covin, 1995) which suggested relationship exists between entrepreneurial orientation and firm/export performance. The argument for the statistically significant relationship between export performance and EO was based on first prime mover advantage of EO (Zahra \& Covin, 1995). Pro-activeness, innovativeness and risk taking were expected to facilitate a firm to transform its economic performance (Naman \& Slevin, 1993). In addition, complex, uncertain and turbulent nature of export market environment was expected to encourage and provide better opportunity for better success (Balabanis and Katsikea, 2003). The result of hypothesized relationship between reconfiguring capability and export performance is also consistent with the available prior studies (Jantunen et al., 2005). 
This study complements existing studies and the outcome suggests it is not only sufficient for SMEs to adopt an entrepreneurial behavior but more importantly its ability to create new asset configuration that have effect on export performance. The study specifically provide pragmatic support for dynamic capability view of the firm, emphasizes the ability to orchestrate change and organize efficiently in order to take advantage of new opportunities (Jantunen et al., 2005; Teece et al., 1997). The finding of this study implies that international organization capability is not only important for established companies and born-global but also more important for SMEs operating in foreign market. The Moderation of environmental turbulence on the relationship between entrepreneurial orientation and export performance is also consistent with the prior literature (Cadogan, 2009; Boso et al., 2012; Yeoh \& Jeong, 1995; Lumpkin \& Dess, 2001; Covin \& Slevin, 1989; Wilklund \& Shepherd; Boso et al., 2012; Sundqvist, Kylaheiko, Kuivalainen \& Cadogan, 2012), that environmental turbulence is a potential contingent factor that could influence the effectiveness of the usage of the strategic orientations (Lumpkin \& Dess, 2001). The significant moderating effect of environmental turbulence on the relationship between reconfiguring capability and export performance is consistent with the view that reconfiguring capability is most valuable when the external environment is changing. Teece et al. (1997) buttressed this view by describing reconfiguring capability as the firm's ability to address rapidly changing environment.

Figure 2: Interaction Effect of reconfiguring capability and Environmental Turbulence on Export Performance

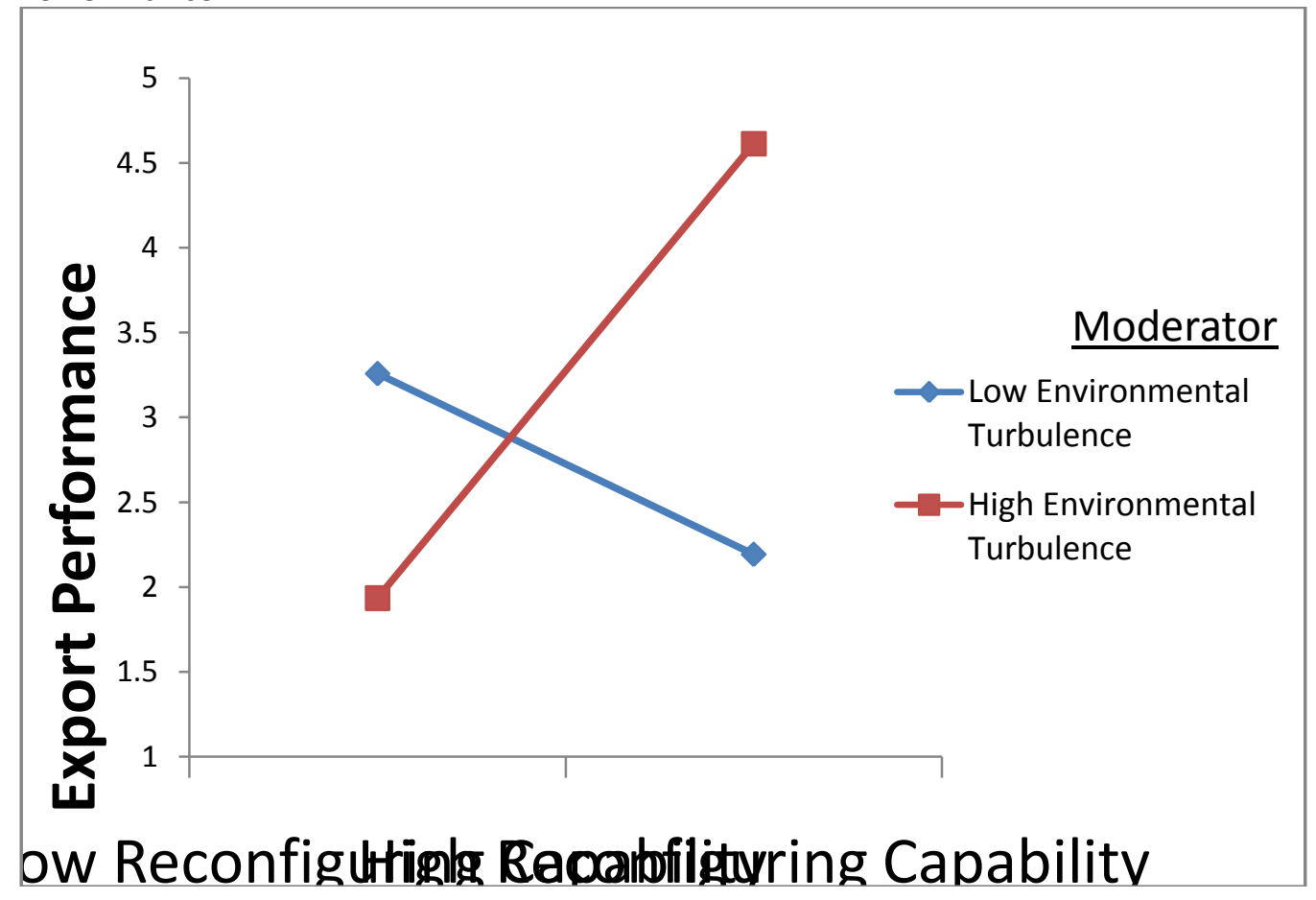

\section{Conclusion}

This study makes contribution to the literature of SMEs' export performance in international entrepreneurship and strategy research by examining the impact of the firm's reconfiguring capabilities and entrepreneurial strategic orientation under environmental turbulence on export performance. To the best knowledge of these researchers, this effect has not been empirically investigated previously in this manner. Even though there have been studies on the relationship between strategic orientations and export performance (Cadogan, Kuivalainen \& Sundqvist, 2009; Cadogan et al., 2001; Cadogan, Sundqvist, Puumalainen \& Salminen, 2012; Knight \& Cavusgil, 2004). This study in particular complements existing studies. The outcome suggests that it is not only strategic entrepreneurial and export marketing behavior but more importantly the ability to create new asset configuration that have an effect on export performance of SMEs. One of the major contributions of this study is to use reconfiguration to provide a view into slogan of 
innovation within SMEs. This study refers to the ability to manage resources and structure as reconfiguring capability (Karim and Mitchel, 2004). Therefore, firms with advanced reconfiguring capabilities bundled with strategic orientations might be expected to seize opportunity through new resources combination and well organized process and structures. The contribution of this study also extends resources based view (RBV) as an appropriate theoretical perspective for emerging market by providing evidence for export performance of SMEs. In this study EO is considered as resources which have potentials to enhance export performance.

Furthermore, the moderating effect of the relationship was statistically significant for entrepreneurial orientation, reconfiguring capability with export performance for exporting SMEs in high turbulent environment than for exporting SMEs in low turbulent environment. This suggests that, SMEs' exporter could derive greater benefit in investing in research into reducing cost, better efficient distributing system, innovative products, good technologies and all activities that can improve and drive export market and thereby increase sales and growth. Moreover, under environmental turbulence, this study provides support for the usage of entrepreneurial orientation and reconfiguring capability, the finding depicts that RC and EO would be more valuable when there is environmental turbulence and could become less effective when there is stability in the environment. Hence, SMEs should invest more in research and development to offset environmental turbulence which would yield better performance than the competitor that has not taken the same measure.

Recommendations: Based on the findings of this study, the following course of actions are suggested; First, SMEs who pays relatively more emphasis on profitability, growth and satisfaction could invest more in reconfiguring their assets. Such export manager of SMEs should emphasize reconfiguration of capabilities development and market penetration in their exporting activities (Abiodun \& Rosli, 2014; Jantunen et al., 2005). Second, Government agencies and stakeholders in exporting SMEs, particularly in the context of the sample in this study should leverage renewal strategy on incentives giving to SMEs and reconfigure contribution in the following dimensions; revamping all old Industrial Development Centre and establish new ones (IDCs); establishing SMEs clusters ; upgrading rural urban road. Government in attempt to develop and reconfigure capabilities should introduce entrepreneurial studies; emphasize science, practical and technological studies at all level of educational system. There should be education department to be responsible for public enlightenment and training of exporting entrepreneurial SMEs most especially on required technological and marketing skills to enable them to have appropriate linkage to source raw materials, plant machines and spare parts that would give rise to standard products that can penetrate to the global market. Third, exporting SMEs managers could consider risk taking decision in turbulent environment as it improves performance (Calantone, Garcia \& Dröge, 2003). SMES should be pro-active, innovative, risk seeking posture to mitigate the uncertainty of turbulent environment (Cadogan et al., 2009). Fourth, this study was conducted within one of developing countries, Nigeria, there would be serious implication in making general inference from this explorative study and caution must be taken in concluding that the outcomes of the study are valid for all entrepreneurial exporting SMEs in general. As such, the findings should be validated at different setting to find whether the findings apply to SMEs exporters in different countries and emerging markets. Fifth, this investigation focuses on the elements of reconfiguring capabilities as one of the processes of dynamic capabilities, however, scholar like Zollo and Winter (2002) perceived dynamic capabilities as a set of complicated processes and operating routines that reflects a learned and stable pattern other than narrow description of how SMEs should be reconfigured. Further study could therefore consider thorough reflection of learning and stability during deletion, recombination and general consolidation's reconfiguring processes. Sixth, the measures of reconfiguring capabilities 'items that were adopted from Jantunen et al. (2005) are too broad about the industry and market change as it narrowly focused on SMEs. Future research could develop more refined measures of reconfiguring capabilities by considering specific aspects such as resources reconfiguration and resources recombination.

\section{References}

Abiodun, T. S. \& Rosli, M. (2014). The mediating effect of reconfiguring capabilities on the relationship between entrepreneurial orientation and export performance of small and medium enterprises. European Journal of Business and Management, 6(34), 345-357. 
Adegbite, S., Ilori, M., Irefin, I., Abereijo, I. \& Aderemi, H. (2007). Evaluation of the impact of entrepreneurial characteristics on the performance of small scale manufacturing industries in Nigeria. Journal of Asia Entrepreneurship and Sustainability, 3(1), 1-22.

Aiken, L. \& West, S. (1993). Detecting interactions in multiple regression: Measurement error, power, and design considerations. The Score, 16(1), 7-15.

Anger, B. (2010). Poverty eradication, Millennium development goals and sustainable development in Nigeria. Journal of sustainable development, 3(4), 138.

Baker, W. E. \& Sinkula, J. M. (2009). The Complementary Effects of Market Orientation and Entrepreneurial Orientation on Profitability in Small Businesses. Journal of Small Business Management, 47(4), 443464.

Balabanis, G. I. \& Katsikea, E. S. (2003). Being an entrepreneurial exporter: does it pay? International Business Review, 12(2), 233-252.

Boso, N., Cadogan, J. W. \& Story, V. M. (2012). Complementary effect of entrepreneurial and market orientations on export new product success under differing levels of competitive intensity and financial capital. International Business Review, 21(4), 667-681.

Cadogan, J. W., Kuivalainen, 0. \& Sundqvist, S. (2009). Export market-oriented behavior and export performance: quadratic and moderating effects under differing degrees of market dynamism and internationalization. Journal of International Marketing, 17(4), 71-89.

Cadogan, J. W., Paul, N. J., Salminen, R. T., Puumalainen, K. \& Sundqvist, S. (2001). Key antecedents to "export" market-oriented behaviors: a cross-national empirical examination. International Journal of Research in Marketing, 18(3), 261-282.

Cadogan, J. W., Sundqvist, S., Puumalainen, K. \& Salminen, R. T. (2012). Strategic flexibilities and export performance: The moderating roles of export market-oriented behavior and the export environment. European Journal of Marketing, 46(10), 1418-1452.

Calantone, R., Garcia, R. \& Dröge, C. (2003). The effects of environmental turbulence on new product development strategy planning. Journal of Product Innovation Management, 20(2), 90-103.

Calantone, R. J., Kim, D., Schmidt, J. B. \& Cavusgil, S. T. (2006). The influence of internal and external firm factors on international product adaptation strategy and export performance: a three-country comparison. Journal of Business Research, 59(2), 176-185.

Cavusgil, S. T. (1984). Differences among exporting firms based on their degree of internationalization. Journal of Business Research, 12(2), 195-208.

Cavusgil, S. T. \& Zou, S. (1994). Marketing strategy-performance relationship: an investigation of the empirical link in export market ventures. The Journal of Marketing, 24(1), 1-21.

Chin, W. W. (1998). Commentary: Issues and opinion on structural equation modeling: JSTOR.

Covin, J. G. \& Slevin, D. P. (1989). Strategic management of small firms in hostile and benign environments. Strategic management journal, 10(1), 75-87.

Dawson, J. F. \& Richter, A. W. (2006). Probing three-way interactions in moderated multiple regression: development and application of a slope difference test. Journal of Applied Psychology, 91(4), 917.

Dess, G. G. \& Beard, D. W. (1984). Dimensions of organizational task environments. Administrative Science Quarterly, 29, 52-73.

Duarte, P. A. O. \& Raposo, M. L. B. (2010). A PLS model to study brand preference: An application to the mobile phone market Handbook of partial least squares (pp. 449-485): Springer.

Eisenhardt, K. M. \& Bourgeois, L. J. (1988). Politics of strategic decision making in high-velocity environments: Toward a midrange theory. Academy of management journal, 31(4), 737-770.

Garcia, R. \& Calantone, R. (2002). A critical look at technological innovation typology and innovativeness terminology: a literature review. Journal of product innovation management, 19(2), 110-132.

Gibson, C. B. \& Birkinshaw, J. (2004). The antecedents, consequences, and mediating role of organizational ambidexterity. Academy of management Journal, 47(2), 209-226.

Glazer, R. \& Weiss, A. M. (1993). Marketing in turbulent environments: decision processes and the timesensitivity of information. Journal of Marketing Research, 30(11), 509-521.

Hair, J. F., Hult, G. T. M., Ringle, C. \& Sarstedt, M. (2013). A primer on partial least squares structural equation modeling (PLS -SEM. Thousand Oaks, California.

Hair, J. F., Ringle, C. M. \& Sarstedt, M. (2011). PLS-SEM: Indeed a silver bullet. The Journal of Marketing Theory and Practice, 19(2), 139-152. 
Hair, J. F., Sarstedt, M., Pieper, T. M. \& Ringle, C. M. (2012). The use of partial least squares structural equation modeling in strategic management research: a review of past practices and recommendations for future applications. Long Range Planning, 45(5), 320-340.

Henseler, J. \& Ringle, C. (2009). The Use of Partial Least Squares Path Modeling in International Marketing. In: New Challenges to International Marketing, Sinkovics, RR. and PN Ghauri (Ed). Vol. 20: Emerald Group Publishing Ltd., Bingley, UK, ISBN.

Henseler, J., Ringle, C. M. \& Sinkovics, R. R. (2009). The use of partial least squares path modeling in international marketing. Advances in international marketing, 20, 277-319.

Jantunen, A., Puumalainen, K., Saarenketo, S. \& Kyläheiko, K. (2005). Entrepreneurial orientation, dynamic capabilities and international performance. Journal of International Entrepreneurship, 3(3), 223243.

Julien, P. A. \& Ramangalahy, C. (2003). Competitive strategy and performance of exporting SMEs: an empirical investigation of the impact of their export information search and competencies. Entrepreneurship Theory and Practice, 27(3), 227-245.

Karim, S. \& Mitchell, W. (2004). Innovating through acquisition and internal development: A quarter-century of boundary evolution at Johnson \& Johnson. Long Range Planning, 37(6), 525-547.

Kaynak, E. \& Kuan, W. K. Y. (1993). Environment, strategy, structure, and performance in the context of export activity: an empirical study of Taiwanese manufacturing firms. Journal of Business Research, 27(1), 33-49.

Knight, G. A. \& Cavusgil, S. T. (2004). Innovation, organizational capabilities, and the born-global firm. Journal of International Business Studies, 35(2), 124-141.

Kohli, A. K., Jaworski, B. J. \& Kumar, A. (1993). MARKOR: a measure of market orientation. Journal of Marketing research, 30(4), 467-477.

Krejcie, R. V. \& Morgan, D. W. (1970). Determining sample size for research activities. Educ Psychol Meas.

Lechner, C. \& Gudmundsson, S. V. (2014). Entrepreneurial orientation, firm strategy and small firm performance. International Small Business Journal, 32(1), 36-60.

Lindelöf, P. \& Löfsten, H. (2006). Environmental Hostility and Firm Behavior-An Empirical Examination of New Technology-Based Firms on Science Parks. Journal of Small Business Management, 44(3), 386406.

Lumpkin, L. \& Dess, G. G. (1996). Clarifying the entrepreneurial orientation construct and linking it to performance. Academy of management Review, 21(1), 135-172.

Lumpkin, G. T. \& Dess, G. G. (2001). Linking two dimensions of entrepreneurial orientation to firm performance: The moderating role of environment and industry life cycle. Journal of business venturing, 16(5), 429-451.

Miller, D., Dröge, C. \& Toulouse, J. M. (1988). Strategic process and content as mediators between organizational context and structure. Academy of Management Journal, 31(3), 544-569.

Miller, D. \& Friesen, P. H. (1983). Strategy-making and environment: The third link. Strategic management journal, 4(3), 221-235.

Naman, J. L. \& Slevin, D. P. (1993). Entrepreneurship and the concept of fit: a model and empirical tests. Strategic management journal, 14(2), 137-153.

Ogunsiji, A. (2002). A Review of Business Process Reengineering as a Strategic Management Option. J. Business and Common Market Studies, 1(1).

Ogunsiji, A. S. (2010). Entrepreneurial Orientation as a Panacea for the Ebbing Productivity in Nigerian Small and Medium Enterprises: A Theoretical Perspective. International Business Research, 3(4), 192.

Okpara, J. 0. (2009). Strategic choices, export orientation and export performance of SMEs in Nigeria. Management Decision, 47(8), 1281-1299.

Okpara, J. O. \& Kabongo, J. D. (2009). Entrepreneurial Export Orientation, Strategy, and Performance of SMEs in an Emergent African Economy. Afr. J. Bus. Econ. Res, 4(2\&3), 34-54.

Okpara, J. O. \& Koumbiadis, N. J. (2009). Strategic export orientation and internationalization barriers: evidence from SMEs in a developing economy. Journal of International Business and Cultural Studies, $1(1), 1-10$.

Onugu, B. A. N. (2005). Small and medium enterprises (SMEs) in Nigeria: Problems and prospects. St. Clements University, Nigeria (Unpublished Dissertation for a Doctor of Philosophy in Management Award). 
Oyefuga, I. O., Siyanbola, W. O., Afolabi, O. O. \& Dada, A. D. (2008). SMEs funding: an assessment of an intervention scheme in Nigeria. World Review of Entrepreneurship, Management and Sustainable Development, 4(2), 233-245.

Sapienza, H. J., Autio, E., George, G. \& Zahra, S. A. (2006). A capabilities perspective on the effects of early internationalization on firm survival and growth. Academy of Management Review, 31(4), 914-933.

Sekaran, U. \& Bougie, R. (2013). Research Methods for Business (6th ed.). United Kindom: John Wiley \& Son Ltd.

Sundqvist, S., Kyläheiko, K., Kuivalainen, O. \& Cadogan, J. W. (2012). Kirznerian and Schumpeterian entrepreneurial-oriented behavior in turbulent export markets. International Marketing Review, 29(2), 203-219.

Teece, D. J., Pisano, G. \& Shuen, A. (1997). Dynamic capabilities and strategic management. Strategic management journal, 18(7), 509-533.

Wiklund, J. (1999). The sustainability of the entrepreneurial orientation-performance relationship. Entrepreneurship theory and practice, 24(1), 37-48.

Wiklund, J. \& Shepherd, D. (2003). Knowledge-based resources, entrepreneurial orientation, and the performance of small and medium-sized businesses. Strategic management journal, 24(13), 13071314.

Wiklund, J. \& Shepherd, D. (2005). Entrepreneurial orientation and small business performance: a configurational approach. Journal of business venturing, 20(1), 71-91.

Winter, S. G. (2003). Understanding dynamic capabilities. Strategic management journal, 24(10), 991-995.

Wold, H. (1985). Partial least squares. Encyclopedia of statistical sciences.

Yeoh, P. L. \& Jeong, I. (1995). Contingency relationships between entrepreneurship, export channel structure and environment: a proposed conceptual model of export performance. European Journal of Marketing, 29(8), 95-115.

Zahra, S. A. \& Covin, J. G. (1995). Contextual influences on the corporate entrepreneurship-performance relationship: A longitudinal analysis. Journal of business venturing, 10(1), 43-58.

Zahra, S. A. \& George, G. (2002). Absorptive capacity: A review, reconceptualization, and extension. Academy of management review, 27(2), 185-203.

Zahra, S. A., Sapienza, H. J. \& Davidsson, P. (2006). Entrepreneurship and dynamic capabilities: a review, model and research agenda. Journal of Management studies, 43(4), 917-955.

Zollo, M. \& Winter, S. G. (2002). Deliberate learning and the evolution of dynamic capabilities. Organization Science, 13(3), 339-351.

Zou, S., Taylor, C. R. \& Osland, G. E. (1998). The EXPERF scale: a cross-national generalized export performance measure. Journal of International Marketing, 6(3), 37-58. 